\title{
6 HRONICLES
}

\section{KRONIK FILSAFAT}

BELANDA - Kongres. - Pada 7 hingga 13 Juni 2020 akan diselenggarakan kongres filsafat lima hari dengan berpusat pada karya-karya Hans Achterhuis. Kongres ini diorganisasi oleh Amor Mundi. Lima hari itu mengacu pada kelima tema yang mengambil tempat sentral dalam pemikiran Achterhuis dan yang akan dipakai sebagai kerangka untuk membicarakan karya-karyanya. 'Filosofieweek' ini akan diadakan di suatu perkebunan di Verdon, Prancis. Informasi lebih lanjut bisa didapatkan di www.amormundi.info.

INGGRIS - Nekrologi. - Roger Scruton meninggal dunia pada 7 Januari 2020 yang lalu. Ia lahir pada 1944 di Manchester. Setelah studi filsafat, ia aktif di berbagai posisi akademis di Inggris dan Amerika Serikat, tetapi terutama dikenal sebagai intelektual publik dan salah satu perwakilan terpenting konservatisme. Karyanya juga dikenal di Flams dan Belanda. Ia menerbitkan lebih dari 50 buku mengenai berbagai subjek, dan juga berbagai karya fiksi dan dua opera. Beberapa karyanya yang terkenal ialah Art and Imagination: A Study in the Philosopby of Mind (1974), The Aesthetics of Architecture (1979), The Meaning of Conservatism (1980), A Short History of Modern Pbilosophy (1982), Sexual Desire: A Philosophical Investigation (1986), The Classical Vernacular: Architectural Principles in an Age of Nibilism (1995), The Aesthetics of Music (1997), dan Conservatism: An Invitation to the Great Tradition (2017).

Pada 3 Februari yang lalu di Cambridge, Georges Steiner meninggal dunia. Ia lahir di Neuilly-sur-Seine pada 1929, dari keluarga Yahudi-Austria. Sebelum perang, keluarganya melarikan diri ke Amerika Serikat. Di sana ia menjalani studi antara lain di universitas Chicago dan Harvard. Setelah berbagai pengembaraan akademis, pada 1974 ia menjadi guru besar studi sastra komparatifdi universitas Jenewa dan setelah emeritatnya pada 1994 ia menjadi guru besar poetika di universitas Oxford dan Harvard. Karyanya bersifat literal, kultur-historis, dan filosofis, serta membahas subjek-subjek literatur, religi, musik, lukisan, dan sejarah. Dampak 'Holocaust' terbawa 
dalam karya-karyanya dan mengambil tempat yang penting. Karya-karya yang terkenal antara lain Tolstoy or Dostoevsky (1959), Language and Silence (1967), In Bluebeard's Castle: Some Notes Towards the Redefinition of Culture (1971), After Babel (1975), Real Presences (1986), Grammars of Creation (2002), dan Lessons of the Masters (2003).

PRANCIS - Nekrologi. - Alexandre Matheron meninggal dunia di Paris pada 7 Januari 2020 yang lalu. Ia lahir pada 1926, studi ilmu politik dan filsafat dan pada 1956 menyelesaikan studinya. Sejak 1957 hingga 1963 ia mengajar di Algiers, kemudian ia kembali ke Paris dan bekerja sejak 1963 hingga 1968 di bawah bimbingan M. Guéroult di CNRS. Pada 1968 ia menyelesaikan studi doktoralnya berjudul Individu et communauté chez Spinoza. Ia menjadi asisten di Universitas Nanterre dan pada 1971 menjadi guru besar di Universitas Lyon. Karya-karya pentingnya ialah Le Christ et le salut des ignorants chez Spinoza (1971) dan berbagai artikel, dibundel dalam Anthropologie et politique au XVIIe siècle: Études sur Spinoza (1985) dan Études sur Spinoza et les philosophies à l'âge classique (2011).

BELGIA - Terbitan Berkala. - Edisi 4-2019 jurnal De Uil van Minerva mengarahkan fokus artikel-artikelnya pada peristiwa meninggalnya Rudolf Boehm dan pada pengaruhnya serta pembahasan-pembahasan tentang karyanya. J. De Visscher menuliskannya dalam In memoriam. Selanjutnya terdapat tiga artikel dari Boehm dalam terjemahan bahasa Belanda: Metafysiek en fenomenologie, Twee gezichtspunten: Husserl en Nietzsche serta Ons aller hopeloos Marxisme. Pembahasan tentang pemikiran-pemikiran Boehm dilakukan oleh F. Mestrum, J. Versieren, L. Vanneste, dan R. Debaene.

\section{KRONIK TEOLOGI}

\section{Angkatan Bersenjata yang Terinspirasi Spiritualitas}

(Tilburg, 30 Oktober 2019)

Pada 30 Oktober 2019 yang lalu di Tilburg, Belanda, diselenggarakan simposium yubileum sehubungan dengan bidang studi profesorat 
spiritualitas di dalam angkatan bersenjata. Tema yang diangkat ialah "Edukasi Perdamaian dan Aksi Militer - Perlunya Sebuah Angkatan Bersenjata yang Terinspirasi". Setelah pembukaan oleh M. Sarot dan pengantar tema oleh ketua bidang studi profesorat F. van Iersel - keduanya dari Tilburg School of Theology (TST) - dengan fokus pada kemungkinankemungkinan yang muncul dari posisi gereja-gereja di margin kekuasaan dan mencegah kekerasan secara aktif. M. van Reisen (Tilburg University) membuat sketsa tentang tantangan-tantangan bagi suatu perdamaian yang berdasar pada keadilan dalam sebuah dunia yang sangat teknologis ini.

R. van Eijk (Kementerian Hukum dan Keamanan) menggambarkan situasi tematik bagi etika penanganan spiritual dan bagian-bagian yang lemah daripadanya. P. Vos (PTHU Amsterdam) melukiskan kontur suatu etika yang mengintegrasikan utilisme, etika moral dan etika kebajikan Kantian dalam angkatan bersenjata. E. Sengers selanjutnya membahas bagaimana ajaran sosial Katolik dapat terkait dengan perang dan perdamaian di tingkat penanganan personal militer.

Dalam dimensi internasional problematika tersebut, R. Zaviyski (Ukrainian Catholic University, Lviv) menjelaskan suatu perspektif politik-teologis tentang perlu dan mendesaknya penanganan spiritual di negara yang terlibat peperangan, dengan mengambil contoh Ukraina sebagai kasus. V. Bock (Zentrum für ethische Bildung in den Streitkräften, Hamburg) menjelaskan dari perspektif teologi moral peran edukatif gereja dan penanganan spiritual di Jerman, baik sehubungan dengan tema-tema 'hardware' dari etika militer, maupun perang informasi dan adanya perang hibrid. Para kandidat profesorat bidang studi ini kemudian mempresentasikan gambaran proyek-proyek mereka seputar perkembangan dalam moral perdamaian Vatikan dan persoalan Irlandia Utara.

Dua pendeta mempromosikan juga proyek mereka: B. van Dijk tentang tempat formasi moral dalam diri pendeta angkatan bersenjata dan S. Brouwers tentang moral injury sebagai tema penelitian dan tema dalam praktik pastoral. Ketua kegiatan ini kemudian menawarkan sebuah terbitan mengenai refleksi atas tradisi "perang yang benar" dari Vatikan di bawah Paus Fransiskus, berjudul The Future of Just War Theory: A Catholic Approach. 
Diskusi-diskusi selanjutnya menarik perhatian peserta antara lain sehubungan dengan pertukaran paradigma dalam etika perang yang benar menuju perdamaian yang benar, yakni apakah tema tersebut lebih dari sekadar semantik. Etika perdamaian yang berdasar pada "Perdamaian yang benar" tentu saja dimulai dengan pencegahan konflik, upaya perdamaian dan rekonsiliasi, tetapi juga meliputi subjek tentang legitimitas eskalasi konflik bersenjata. Mengenai penanganan spiritual ini ditarik kesimpulan penting bahwa di Belanda fokus lebih diarahkan pada persoalan-persoalan etis militer, dan karenanya, persoalan-persoalan yang lebih sulit tidak bisa dikesampingkan. Perhatian yang lebih besar diperlukan demi aspek-aspek sistemik penanganan spiritual dan tidak hanya dibatasi pada penanganan personel-personel tertentu.

\section{Hukum Kriminal dan Religi}

(Tilburg, 14 November 2019)

Universitas Tilburg mengorganisasi kongres ke-4 tentang kejahatan pada 14 November 2019. Sejak 2012, departemen ekumenis Centrum voor Justitiepastoraat bersama dengan para ahli hukum kriminal Tilburg University dan beberapa universitas lain mengorganisasi kongres-kongres ini, dan kali ini temanya ialah religi dan hukum kriminal. Tahun lalu, kongres diadakan di Universitair Centrum voor Geestelijke Verzorging (UCGV). Latar belakang kongres ialah: Arah religi sering digambarkan dalam sejarah dan aktualitas. Kesaksian-kesaksian, konsepsi, dan praktik religius bisa menginspirasi, tetapi juga mengancam; menghibur tetapi juga provokatif; semua itu bisa meneguhkan keseharian, tetapi juga mendorong pada tindakan kelewatan dan kriminal. Bagaimana pemikiran para penanggung jawab tiga agama monoteistis mengenai tindakan kriminal dan tanggung jawab kita atasnya, khususnya dengan hukum kriminal sekuler? Kapan para penanggung jawab hukum kriminal (ahli hukum, advokat, petugas penjara) menemukan aspek-aspek religius dalam pekerjaan mereka? Dan seberapa 'sekuler' hukum kriminal ini sebenarnya? Masihkah kita temukan akar-akar dan warisan religiusnya? Apa yang bisa dipelajari hukum kriminal barat dari kebijakan-kebijakan kehidupan dan religi-religi? 
Di dalam pertanyaan-pertanyaan penuntun tersebut para penanggung jawab agama-agama monoteistis diminta menggambarkan dari titik tolak tertentu tradisinya pembicaraan yang dilakukan dengan orang yang melakukan kejahatan dan karenanya menjalani hukuman. Pengurus spiritual C. Zeidler menjelaskan bahwa manusia menurut tradisi Yahudi sekaligus memiliki jetser hara, suatu motif jahat, dan jetser hatov, suatu motif baik. Motif jahat ada di dalam diri manusia, tetapi kejahatan itu sendiri berasal dari luar. Taurat menegaskan bahwa manusia, ciptaan dengan kehendak bebas, dapat jatuh; Allah menoleransi kesalahan-kesalahan kita agar kita dengan jatuh dan bangkit dapat bertumbuh. Zeidler di sini memberikan banyak contoh dari Kitab Mazmur yang menunjukkan bahwa Allah mengampuni orang yang dengan tulus hati tesjouva (berbalik, menyesal, bertobat). Allah karenanya adalah hakim sekaligus bapa yang pengampun.

Teolog dan pelayan spiritual P. De Witte (Katholieke Universiteit Leuven) mencoba menganalisis tanggapan Protestan dan Katolik terhadap pertanyaan apa yang dilakukan Kristianitas terhadap pelaku kejahatan. Ia mereformulasi ajaran pembenaran Luther (pendosa yang percaya pada tindakan penyelamatan Allah dalam Kristus dalam pandangannya dapat dibenarkan) dalam pasangan istilah keadilan dan belas kasihan. Keadilan Allah menurut Paulus berasal dari suatu tatanan yang sama sekali lain dari keadilan kita (setiap orang mendapatkan yang setimpal dengan perbuatannya). Sebelum manusia menilai tinggi dirinya secara etis, Allah menghargai orang yang benar untuk menyelamatkan orang yang berdosa Yesus mendatangi para pelacur dan pemungut cukai, dan anak yang hilang disambut dengan pesta: "Keadilan-Nya tampak bagi pendosa sebagai belas kasihan". De Witte mengingatkan juga terhadap identifikasi terlalu cepat antara 'pendosa' dalam pengertian kristiani dan pelaku kejahatan. Pengalaman mengajarkan bahwa ada orang yang di luar penjara dan hidup dengan baik tapi tanpa kasih, dan ada yang di dalam penjara tapi hidupnya penuh kasih. De Witte kemudian membuat rangkuman mengejutkan berdasarkan pemikiran ekseget Lutheran, Stendhal, tentang keadilan dan belas kasihan. Disimpulkan bahwa bentuk keadilan sebagai 'pembalasan': penjahat dihukum, tetapi 'pembalasan' ini adalah belas kasihan Allah kepada para janda, anak yatim-piatu, korban, dan yang tertindas. Kitab Suci karenanya membawa perspektif victimologistis. 
Pimpinan Islamitische Geestelijke Verzorging S. Bagci menerangkan beberapa titik tolak diskusi Islamistis dengan tahana: seluruh hidup seseorang di sini sangat penting, kehidupan fisik dan rohani membentuk kesatuan, serta bahwa kehidupan duniawi dan kehidupan kelak ada di dalam perkara hukum. Al Quran menyatakan bahwa manusia bagaimanapun diciptakan lemah $(4,27)$, tetapi juga bahwa mematikan seorang manusia adalah sama dengan mematikan kemanusiaan $(5,32)$. Dalam kerangka ini perjuangan dengan nafs (ego) adalah perjuangan terbesar. Bagci menjelaskan mengenai berbagai dimensi pertobatan (tawba): refleksi diri, empati dan sesal, minta pengampunan, tapi juga perubahan aktif perilaku, sehingga terbuka kemungkinan harapan dan perbaikan.

Dalam paparannya berjudul "Akar-Akar Religius Hukum Kriminal", iuris J. ten Voorde (Universitas Leiden) menekankan bahwa tidak sederhana bagi seorang iuris untuk menjawab pertanyaan "apa itu religi". Ia mengarahkan perhatian pada diskusi tentang perilaku-perilaku religius (misalnya, ritual pengorbanan tanpa bius) dan apakah mesti melindungi atau tidak kelompok-kelompok karena religinya. Secara historis di Belanda ada kesiapan untuk menimbang kesaksian religius, seperti halnya kesempatan untuk pertimbangan hati nurani (religius). Akan tetapi, ia menunjukkan terutama 'rasionalisasi' hukum kriminal, ketika gereja lewat prosedur semakin lama semakin menjauh dari hukum kriminal.

Di sesi siang hari disampaikan paparan menarik ahli sejarah seni W. van Zeil mengenai kejahatan dan hukuman dalam seni religius, dan sesi ini dilanjutkan dengan enam lokakarya: tentang radikalisasi dalam Islam; tentang penyalahgunaan seksual dalam Gereja Katolik Roma dari perspektif korban; tentang persoalan "katekismus sekuler" yang melindungi hak asasi manusia minoritas maupun mayoritas; tentang hukum kriminal lanjut dan antisemitisme baru; tentang alternatif-alternatif hukum kriminal yang terinspirasi religius, dan tentang persoalan religi atau gereja mana yang menarik bagi para bekas tahanan. 


\section{"Out of the Blue"}

(Utrecht, 14 November 2019)

Genootschap voor Liturgiestudie mengorganisasi simposium dua tahunannya dalam kerja sama dengan Liturgische Kring en Luce (TST Tilburg) pada 14 November 2019 yang lalu. Tema yang diangkat ialah "Out of the Blue: Ruang bagi Roh Kudus dalam Liturgi". Acara yang menarik perhatian ini mendatangkan lima puluhan peserta di Catharijnenconvent, Utrecht, Belanda.

T. Pott, OSB (Sant' Anselmo, Roma, Pauselijk Oosters Instituut, Roma, dan biarawan keabasan Chevetogne, Belgia) menjelaskan dari tradisi liturgis Byzantin bahwa pengertian timur mengenai liturgi dan sakramen, dan sebetulnya juga seluruh kehidupan kristiani, dipandang dari mysterion sebagai pengertian dinamis bagaimana Roh Kudus selalu dan di manamana hadir dalam gereja-gereja Ortodoks. Dari tiga ritual liturgis - epiklese dalam anafora Krisostomos, ritus tahbisan imamat, dan doa pengurapan minyak (penguatan) - Pot menunjukkan konkretnya. Ia juga menjelaskan dengan contoh-contoh itu bagaimana ritual dan teologi dapat berfungsi sebagai pegangan sehubungan dengan Roh Kudus, juga di dalam gerejagereja timur. Meskipun Roh tidak pernah dapat dibekukan dan mesti tetap dinamis, sering kali di dalam ritus-ritus Byzantin terkunci baik secara deduktif (dalam beberapa teks dan ritus) maupun secara induktif (dari perspektif soteriologis), menurut Pott.

Pembicara kedua ialah K. van der Kooi (VU Amsterdam). Berbeda fokus dari pembicara sebelumnya, van der Kooi mengarahkan perhatian pada beberapa praktik liturgis yang memberi kesan bahwa Roh Kudus seperti tertidur. Sebagaimana Pott, Van der Kooi yang adalah guru besar Protestan bicara tentang dinamika Roh dan menganalisisnya, apakah menghilang di dalam liturgi. Oleh karenanya bagi Van der Kooi relasi asimetris struktural antara Allah dan kongregasi dalam liturgi adalah fundamental. Roh hadir sebagai aktor liturgi dan manusia bukanlah aktor utama di sini. Kita tidak bisa memastikan tinggalnya Roh Kudus di antara kita, tetapi mesti memperhatikan bahwa kita jangan sampai kehilanganNya karena terlalu banyak memberi tekanan pada kristologi. 
Pembicara ketiga, kali ini dari Katolik Roma, ialah Jos Moons, SJ (Katholieke Universiteit Leuven dan TST). Moons menggambarkan apa yang disebutnya suatu penemuan kembali Roh selama dan terutama setelah Konsili Vatikan II. Kendati tampaknya ada suatu evolusi positif, ia memperlihatkan melalui analisis menyeluruh liturgis dan linguistik atas doa-doa epiklese dari doa-doa Ekaristi postkonsilier dan bahwa masih banyak hal yang perlu dikerjakan. Roh, menurut Moons, masih jarang dihadirkan sebagai aktor. Moons berharap bahwa lex credendi dan lex orandi lebih menginspirasi dalam hal ini.

Setelah pembicaraan yang cenderung lebih teologis di sesi pagi, setelah makan siang perhatian lebih diarahkan ke pembicaraan hal-hal praktis. Pendalaman soal penghayatan Roh dalam liturgi diwujudkan dengan membuat diskusi panel antara penanggung jawab gereja Evangelis (J. Plantinga), gereja Protestan Belanda (K. van den Broeke), dan seorang imam gereja Katolik yang menggunakan liturgi Latin dan Byzantin (P. Brenninkmeijer). Sesudahnya dilanjutkan dengan tiga sesi lokakarya yang menawarkan fokus pada tema-tema Roh Kudus dalam kaitan dengan berbagai aspek ars celebrandi. T. Borggrefe memimpin lokakarya seputar pembacaan, W. Ruessink tentang musik, dan R. Beurmanjer di lokakarya tentang gerakan dan tarian liturgis. Ketiga lokakarya bersifat interaktif dan para partisipan dilibatkan secara aktif dalam kegiatan. Seluruh simposium ditutup dengan suatu ibadat sore ekumenis, yang diwarnai dengan doa-doa bagi turunnya Roh Kudus.

Panitia simposium cukup puas dengan terselenggaranya rangkaian simposium dua tahunan ini dan menginsinuasikan bakal menerbitkan materinya dalam bundel tematik terbitan sehingga peserta dapat mempelajarinya kembali.

\section{"Social Love"}

(Utrecht, 22 November 2019)

Kardinal P. Turkson pada 22 November 2019 memberikan ceramah dalam rangka Dies Natalis Tilburg School of Theology. Kardinal Turkson adalah prefek sebuah 'dikasteri' (bagian dari Kuria Roma) yang didirikan pada 1 Januari 2017, untuk promosi pengembangan umat manusia, yang 
disebut Caritas Christi urget nos. Judul itu diambil dari 2Kor. 5:14 sebagai salah satu teks Kitab Suci yang dipakai sebagai titik tolak pemikiran mengenai caritas, terarah hingga ensiklik Laudato Si Paus Fransiskus, yang pada nomor 231 berbicara tentang social love sebagai dasar pengembangan manusiawi yang otentik.

Paus Benediktus XVI dalam ensikliknya Caritas in Veritate - dokumen dasar untuk dikasteri baru ini, yang terfokus pada pengungsi dan migran, yang tertindas dan sakit, terpinggirkan dan terusir, para tahanan dan penganggur, korban di tengah konflik bersenjata dan bencana alam, termasuk perbudakan dan penyiksaan - memperlihatkan bahwa bagi caritas kasih Allah dan kasih pada manusia saling bekerja sama. Dengan cara ini caritas membentuk keutuhan yang saling berkaitan dengan evangelisasi dan pengembangan.

Selanjutnya, dikatakan oleh Turkson, bahwa dasar teologis bagi seluruh pengembangan manusiawi terletak dalam Kitab Suci, yang kemudian dibangun oleh para bapa Gereja dan dilaksanakan melalui ajaran sosial Gereja. Sehubungan dengan Kitab Suci, perlu dirujuk Yesaya 24, juga hymne puitis, seperti Mazmur 109:21 (suatu rujukan khusus, sebab Mazmur 109 tidak dibawa ke dalam brevir baru yang setelah Konsili Vatikan II disusun), seperti juga teks-teks Injil, seperti teks klasik Mat. 25:31-46, dan kisah-kisah dalam Kisah Para Rasul. Khususnya Kis. 2:44-47 menunjukkan peran penting, sebab di situ ditekankan keterkaitan antara Sabda Allah, komunitas, dan pelayanan kepada yang miskin. Para bapa Gereja, seperti halnya Yustinus dalam Apologia 1:68, meminta perhatian pada pelayanan kepada orang yang membutuhkan. Sejak ca. 400 ketika orang-orang Kristen tampaknya lebih mempunyai milik pribadi, para bapa Gereja, seperti Ambrosius dalam De Officiis 1,28, 132, menekankan bahwa milik dimaksudkan Allah untuk membawa kebaikan bagi seluruh umat manusia.

Turkson menunjukkan bahwa diskusi gerejawi tentang persoalanpersoalan sosial berkembang tahap demi tahap. Sebagai titik awal ada ensiklik Rerum Novarum pada 1891 dari Paus Leo XIII. Juga selama Konsili Vatikan II ada perhatian pada pemikiran sosial dalam gereja. Gaudium et Spes juga menyinggung hal ini terutama nr. 59. Adalah Paus Paulus VI yang memperkenalkan istilah "pengembangan manusiawi yang integral". Untuk pengembangan ini disebutkan enam aspek (ekonomis, sosial, 
politik, kultural, transenden, dan religius). Sudut pendekatan politik juga dihadapkan pada negara-negara baru masa postkolonial dengan demokrasi yang rapuh atau juga tidak berfungsi. Sayangnya problem ini masih terjadi sekarang, seperti di Libanon, Siria, dan Chile. Paus menekankan bahwa 'person' berarti 'relasi'. Ini berarti 'inklusi' mesti terjadi dan bukan 'eksklusi' dan bahwa martabat manusia tidak boleh dilanggar.

Selanjutnya Turkson merujuk pada aktualitas Sinode Amazon yang diselenggarakan pada Oktober. Seluruh pengembangan manusiawi menurut Sinode terancam oleh ketidakadilan, ketidakacuhan, kelaparan dan hilangnya akses pada pendidikan, penanganan kesehatan, makanan, air, energi, dan 3T. "3T" ini adalah istilah teknis yang berasal dari teologi berbahasa Spanyol. Tiga $T$ tersebut ialah trabajar (kerja), techo (atap di atas kepala, hunian), dan tierra (tanah, kemungkinan pengembangan aktivitas agraris). Turkson mempertanyakan bukan hanya perhatian pada problemproblem "di luar dunia", melainkan juga yang di dalam gereja sendiri. Kardinal yang berasal dari Ghana ini mengisahkan bahwa di Afrika Barat perkataan bahwa darah lebih kental daripada air baptis banyak dikenal. Ketika keanggotaan dalam sebuah suku (atau kasta, seperti di Asia) menghambat pengembangan manusiawi, demikian juga ini menghambat untuk menjadi familia Dei.

Untuk membahas lebih lanjut aspek-aspek teologis tersebut dalam keterkaitannya, dikasteri mengembangkan theologoumenon 'oikos'. Ide tentang sebuah rumah menunjukkan bahwa relasi-relasi adalah penting, bahwa harus ada kasih satu terhadap yang lain, sehingga kasih Allah bisa mendapatkan bentuk.

Akhirnya, Turkson menyampaikan bahwa mereka yang melakukan caritas harus merealisasikan 'kita' seperti yang dikutip dari Paulus dalam caritas Christi urget nos. Karena alasan itulah ia menyampaikan kritik bahwa Paus Fransiskus tampaknya terlalu banyak memberi perhatian pada masalah-masalah sosial. Paus mestinya lebih bersifat mengarahkan dalam perkara-perkara iman dan menjelaskan situasi krisis pengungsi dan migran. 